\title{
Model for Investigating Substitution Effect between Renewable Resources and Non-Renewable Resources
}

\author{
Zhijie Huang \\ Department of finance \\ Fuzhou University of International Study and Trade \\ Fuzhou China \\ prino@sina.cn
}

\begin{abstract}
This paper is mainly about investigating the substitution effect between renewable resources and nonrenewable resources. Firstly, the paper will give a review about previous empirical analysis about the relationship between the two resources. Then, the substitution effect will be analyzed by building a model which is based on reducing form of demand and supply function for gasoline market. This model can be combined with time series data in different countries and appropriate time series test to discover the substitution effect for both resources. The accurate analysis for this substation effect can give government appropriate guidance in terms of reducing greenhouse effect on increasing the usage of renewable resources.
\end{abstract}

Keywords-renewable resources, non-renewable resources, substitution effect, model building

\section{INTRODUCTION}

Intergovernmental panel on climate change and Statista state the dramatic increase in Chinese GDP and the population owned vehicle cause that the greenhouse gas emission tends to become an essential environmental problem in 21 st century. Armstrong and Dr Hamrin (2013) states that renewable resources that are organic natural resources can be supplemented through biological reproduction or other naturally process. [1]The White House Office of the Press Secretary (2007) reports that the president of the US has established a goal of supplying 35 billion gallons per year of renewable resources and alternative fuels by 2017. [2] This policy means that the US government wants to increase the application about renewable resources to reduce the greenhouse effect. However, the feasibility of this policy is a crucial problem to investigate, which is whether the increase of consumption of renewable resources can actually reduce the consumption of fossil fuel. This essay will focus on method about investigating substitution effect between renewable resources and non-renewable resources. This will be done by building a model which can be combined with a set of time series approach to discover the cointegration relationship between the two resources.

\section{LITERATURE REVIEW}

\section{A. Literature about empirical analysis for the relativity} between renewable resources and non-renewable resources

Apergis and Payne (2009) prove that there is bidirectional causality between renewable resources and economic growth by using data from many OECD countries (including US). [3] They use panel unit root, cointegration test and granger causality test to find the relationship between the renewable resources and economic growth and present the cointegration with panel error correction model. The panel causality test results also show that renewable resources consumption makes a positive and significant impact to economic growth in the short run, even having controlled for the effect of real gross fixed capital information and the labor force. This literature shows there is the bidirectional causality relationship between renewable resources consumption and economic growth in both short run and long run. This literature only measures the feasibility of using renewable resources in OECD countries in terms of economic growth and points out that it is necessary to consider the employment factor during the analyses about renewable resources consumption. Furthermore, Apergis and Payne (2011) use panel error correction model to shows the relationship between renewable resources and non-renewable resources and economy growth. [4]The renewable and nonrenewable resources consumption is measured by the maximum amount of electricity produced by each of the energy. The result from panel causality test shows that there is no long-run relationship between two resources. Furthermore, the result demonstrates that the renewable energy consumption makes positive but statistically insignificant impact economic growth, while the economic growth makes positive and significant impact on it. On the other hand, there is a significant bidirectional causality relationship between renewable resources and economic growth.

The other remarkable result in the literature is that only non-renewable resources makes significant impact on employment, while employment make significant impact in neither of two resources consumption. This shows that the 
employment tends not to affect the consumption of renewable resources and non-renewable resources. Tugcu et al (2012) use Autoregressive Distributed Lag (ARDL) approach to estimate the long run relationship between the renewable and nonrenewable energy consumption and economic growth in in G7 countries for 1980-2009 period. [5] This estimation is based on a classical Cobb-Douglas production function which contains labor, capital and Augment production function with all variable in classical production function and additional variable that are R\&D (research and development) and energy. The result shows both resources have positive impact on economy growth. However, the significant level of positive impact is determined by the country and the production function used. And the causality test result of augmented production function estimation shows that only Japan has got causal relationship between non-renewable resources and economic growth. On the other hand, the classical production function estimation indicates there is a bidirectional causal relationship between non-renewable resources consumption and economic growth in all countries. However, the result of causality test built in augmented production function shows that there is no causal relationship between renewable resources consumption and economic growth in France, Italy, Canada and US. The classical production function about renewable energy consumption and economic growth shows the bidirectional relationship between them in the causality test. On the contrary, Tiwari (2011) shows the different result about the impact of renewable resources and non-renewable resources on the economic growth by using data from European and Eurasian countries with a PVAR approach. [6]He states that the growth rate of renewable resources consumption has positive impact on economic growth, while the growth rate of non-renewable resources consumption makes negative impact.

\section{B. Literature about model building (simultaneous equation methodology)}

Beidas-Strom and Pescatori (2014) applies the simultaneous equation method to investigate the effect of demand and supply shocks to oil price and inventories. [7] He combines the demand of oil and supply of oil with futures commodity market to get equilibrium level of stock of oil and the price level of oil. And according to Liu (2011), it is necessary to solve the simultaneity problem between the gasoline price and gasoline demand. [8] He used disposable income and an average gasoline price in neighbor state as an instrument variable to estimate gasoline demand. The instrument variable is used to solve endogeneity problem caused by the correlation the gasoline prices and the error term. This means that it is necessary to use the simultaneous equations to consider both supply side and demand side factors, because the equilibrium consumption of gasoline is determined by both demand and supply side through achieving equilibrium price.

\section{MODEL BUILDING}

The possible approach to estimate the substitution effect about renewable resources and non-renewable resources in China is time series approach which is mainly based on a simply supply and demand function. Here, the gasoline is chosen to be the present of nonrenewable resources, because of its dominant role in the market. On the other hand, the biofuel is used to represent renewable resources, because it is the main substitution for gasoline. The model is reduced form version of the simultaneous equations which contains the demand and supply of gasoline.

\section{A. Demand function}

In demand function, there are three exogenous variables, one endogenous variable and one dependent variable that is the demand of gasoline. The first factor in demand side is employment population. EIA (2016) and Executive office of the president of the United State (2016) state that the tight job market will increase the purchasing power of consumer with employment through the rise of wage, which will lead to the increase of household VMT (vehicle miles traved). [9][10]This means that the employment which represents the labor market will make impact on the demand of gasoline consumption. However, Agerton, Hartley, Medlock III and Temzelides (2015) and Cambridge Econometrics (2015) shows that the consumption of energy has impact on the employment as well. [11-12]This is because the increase in consumption of energy tends to raise the price. Then, the producer will increase the production to make more profit, which will cause the increase in the employment. In order to avoid this endogenous problem, the employment population data need to be with one-month lag. The second factor is the purchasing power of dollar. It measures the goods and services can be purchased with one unit of dollar. Schryder and Peersman (2012) shows that the appreciation of US dollar causes the significant decline of oil demand for 65 oil import countries. [13] The main input of producing gasoline is the crude oil. This means that the purchasing power of US dollar may also affect the demand of gasoline. The third factor is the total consumption of renewable resources, which is also the key variable in this model. This factor will be the total consumption of Ethanol and Biomass-based Diesel. However, the connection between the renewable resources and gasoline is substitute relationship. This means that the increase on using renewable resources may reduce the consumption of gasoline, but vice versa. Then, there will be an endogenous problem between them, because the dependent variable gasoline consumption may affect the consumption of renewable resources. Due to the purpose of investigating the long-run cointegration between them, this problem will not be solved by using lag term of renewable resources. It will be checked with specific test. The last one is the endogenous variable that is the price of gasoline.

Demand function

$$
\begin{gathered}
L Q_{d t}=a_{1}+b_{1} L E M P_{t}+b_{2} I P P_{t}+b_{3} L R_{t}+b_{4} L P_{t} \\
+u_{d t}
\end{gathered}
$$

\section{B. Supply function}

The supply function consists of two exogenous variables, one endogenous variable and one dependent variable that is supply of gasoline. In the supply side, the cost of production is 
an essential factor to consider. That can be divided into the production cost and the input cost which is mainly about the crude oil. The cost of production tends to have no significant fluctuation in the long run level, because it depends on the technology progress. Hence, this paper will focus on the cost of input, which is the price of crude oil. However, according to Archibald and Gillingham (1980), Hausman and Newey (1995), Schmalensee and Stoker (1999), Wadud et al. 2010a and 2010b; the main determinant of gasoline price is the crude oil price. [14-18]This suggests that if we simply regress the supply of gasoline with the crude oil price, the crude oil price will be correlated with the endogenous variable gasoline price. Hence, the paper uses the main determinants of crude oil price to capture the effect of crude oil price. The first factor used is the production cost of crude oil, which is captured by the price of equipment to drill oil. The second factor is the total supply of crude oil in OPEC countries. OPEC produces about 40 percent global oil production and 73 percent of world's oil reserves. And OPEC member countries have more than $80 \%$ of the world's proven oil reserves currently, which is about 1,206.00 billion barrels. This means that OPEC plays an important role in the crude oil market. Furthermore, Alsmiller and Horwedel (1985) developed a dynamic World Oil Market (WOM) model for the period 1980-2040 to build Generalized Equilibrium Modeling System, which analyze the OPEC from Stackelberg cartel and competitive producer separately. [19] And the model shows that full cooperation among OPEC member can cause a $25 \%$ increase in the oil price for 1990 2010. Griffin (1985), Adelman (1982, 1986, 1990 and 1993) and Al-Qahtani, Balistreri and Dahl(2008) use the cartel behavior model to analyze the OPEC's production and price setting. And they demonstrate that the increase in crude oil price is not simply because of the scarcity of resources, but the market power of OPEC. [20-25]Hence, this paper chooses the total supply of crude oil in OPEC as a determine factor affecting the crude oil price. Because of the cartel behavior of OPEC, the production of OPEC will not be a good measure of the impact of OPEC. In other word, the OPEC tends to stock a part of their crude oil to maintain the monopoly profit.

Supply function

$$
L Q_{s t}=a_{2}+d_{1} L C_{t}+d_{2} L O P E C_{t}+d_{3} L P_{t}+u_{s t}
$$

\section{Equilibrium and reduced form}

Then, if the simultaneous equation is solved by substitute equilibrium price and quantity of gasoline, there will be two reduce form. One is about how exogenous variables affecting equilibrium price, the other is the regression about equilibrium quantity. The paper ignores the reduced form for equilibrium price, because main purpose of this paper is to investigate the long-run impact of renewable resources on gasoline consumption. Therefore, the main focus in the paper will be the reduce form contains one dependent variable that is gasoline equilibrium consumption $(\mathrm{Q})$, one key variable that is consumption of renewable resources (R), and four control variables which are employment population (EMP), purchasing power of US dollar (PP), machinery cost of crude oil (C) and the total crude oil supply of OPEC (OPEC). And both key and control variables are assumed to be exogenous variable. In order to make the relationship between them become more linear, all variables are transformed to logarithm in the reduced form. The logarithm is denoted by L. Moreover, due to the monthly data used in the paper, a set of dummy variable which is from $\mathrm{m} 1$ to $\mathrm{m} 12$ will be introduced. This is because monthly data may contain some measurement error which is due to the seasonal effect. It is necessary to regress each variable with the set of dummy variable that capture the effect of each month. That can check whether the variable's data contains seasonal effect. Although it is necessary to check the seasonal effect of each month, there will be only 11 dummy variables in the final model.

Equilibrium quantity

$$
\begin{gathered}
L Q_{t}{ }^{*}=a_{0}+k_{1} L E M P_{t}+k_{2} L P P_{t}+k_{3} L R_{t}+k_{4} L C_{t} \\
+k_{5} L O P E C_{t}+v_{t}
\end{gathered}
$$

Final model

$$
\begin{aligned}
L Q_{t}{ }^{*}=a_{0}+ & k_{1} L E M P_{t}+k_{2} L P P_{t}+k_{3} L R_{t}+k_{4} L C_{t} \\
& +k_{5} L O P E C_{t} \\
& +m_{1}+m_{2}+m_{3}+m_{4}+m_{5}+m_{6} \\
& +m_{7}+m_{9}+m_{10}+m_{11}+m_{12} \\
& +u_{t}
\end{aligned}
$$

\section{Time series approach}

The previous literature reviews about the relationship between the two resources shows that they tend to have different relationship with each other, such as substitution, complementary or no relationship, because of the difference in economic stage or characteristics of specific countries. Hence, if we want to discover whether there is a substation effect between the two resources in a country, then we should combine the real data with this model and use suitable time series approach to test the model. Those time series analyses used to investigate the substation effect of two resources should contains stationary test for data and cointegration test. Due to that the data from real world tends to be non- stationary, which will cause the spurious regression, it is necessary to check the stationary for the data. Then, cointegration test will be conduct to find out whether the two resources have long run cointegration. Cointegration test should include both Engle-granger approach and Johansen test for the purpose of considering both single and multiple cointegrations. Furthermore, if the test result for cointegration shows that there is no cointegration between the two resources, we also need to apply the Granger causality test to find whether they have reversal causality relationship. 


\section{CONCLUSION}

In conclusion, we can combine the model mentioned in the paper with current data to conduct the time series analysis to verify the substitution effect between two resources in China. Then, the government can decide whether apply relative policy to stimulate the production and usage of renewable resources, such as increase the production of renewable resources, or subsidizing the producer of renewable resources, according to the result of time series analysis. This tends to improve the efficiency and effectiveness for the policy about reducing greenhouse effect.

\section{REFERENCES}

[1] Armstrong, A. J. and Dr. J. Hamrin (2013) The Renewable Energy Policy Manual Organization of American States, January 2013

[2] The White House Office of the Press Secretary The White House Office of the Press Secretary http://www.washingtonpost.com/wpdyn/content/article/2007/01/23/AR2007012301091.html 2007

[3] Apergis, N. and Payne, J. E. Renewable energy consumption and economic growth: Evidence from a panel of OECD countries Energy Policy 38 (2010) 656-660, 2009

[4] Apergis, N. and Payne, J. E. Renewable and non-renewable energy consumption-growth nexus: Evidence from a panel error correction model Energy Economics 34 (2012) 733-738 2011

[5] Tugcu, C. T., Ozturk, I. and Aslan, A. Renewable and non-renewable energy consumption and economic growth relationship revisited: Evidence from G7 countries Energy Economics 34 (2012) 1942-1950 2012

[6] Tiwari, A.K., Comparative performance of renewable and nonrenewable energy source on economic growth and $\mathrm{CO} 2$ emissions of Europe and Eurasian countries: a PVAR approach. Econ. Bull. 31 (3), 2356-2372. 2011

[7] Beidas-Strom, S. and Pescatori, A. Oil Price Volatility and the Role of Speculation IMF Working Paper 14/218 2014

[8] Liu, W. Modelling Gasoline Demand in the United States: A Flexible Semiparametric Approach State University of New York at Binghamton 2011

[9] EIA today in energy http://www.eia.gov/todayinenergy/detail.cfm?id=22932, 2016

[10] Executive office of the president of the United State petroleum consumption surprise White house https://www.whitehouse.gov, 2016
[11] Agerton, M.K, Hartley, P., Medlock, K. III and Temzelides, T. Employment Impacts of Upstream Oil and Gas Investment in the United States IMF Working Paper WP/15/28, 2015

[12] Cambridge Econometrics Assessing the Employment and Social Impact of Energy Efficiency http://ec.europa.eu/energy/sites/ener/files/documents/CE_EE_Job s_main\%2018Nov2015.pdf 2015

[13] Schryder, S. D. and Peersman, G. The U.S. Dollar Exchange Rate and the Demand for Oil, 2012

[14] Archibald, R., and Gillingham, R. "An Analysis of the Short-Run Consumer Demand for Gasoline Using Household Survey Data," Review of Economics and Statistics, 62: 622-628., 1980.

[15] Hausman, J., and Newey, W. "Nonparametric Estimation of Exact Consumer Surplus and Dead Weight Loss," Econometrica, 63: 14451476. , 1995.

[16] Schmalensee, R. and, Stoker, T. M. (1999) "Household Gasoline Demand in the United States," Econometrica, 67(3): 645-662.

[17] Wadud, Z., Graham, D. J. and Noland, R. B. "Gasoline Demand with Het- erogeneity in Household Responses," Energy Journal, 31(1): 47-74. 2010a

[18] Wadud, Z., Graham, D. J. and Noland, R. B. "A Semiparametric Model of Household Gasoline Demand," Energy Economics, 32: 93-101. $2010 \mathrm{~b}$

[19] Alsmiller R. G. and Horwedel J. E. "A Model of the World Oil Market with an OPEC Cartel.” Energy, 10 (10): 1089-1102., 1985

[20] Griffin, J. M. "OPEC Behavior: A Test of Alternative Hypotheses." American Economics Review, 75(5): 954-963. , 1985

[21] Adelman, M. A. "Modeling World Oil Supply." Energy Journal, 14(1): 1-32. 1993

[22] Adelman, M. A. "OPEC as a Cartel." in J. M. Griffin and D.J. Teece, OPEC Behavior and World Oil Prices, London: George Allen \& Unwin: 37-63. 1982

[23] Adelman, M. A. "Scarcity and World Oil Prices." Review of Economics and Statistics, 68(3): 387-397. 1986

[24] Adelman, M.A. "The Competitive Floor to World Oil Prices." Energy Journal, 7(4): 9-31. Adelman, M A. (1990) "Mineral Depletion, with Special Reference to Petroleum." Review of Economics and Statistics, Feb.1-10. 1986

[25] Al-Qahtani, A., Balistreri, E. and C. Dahl Literature Review on Oil Market Modeling and OPEC's Behavior Division of Economics and Business, Colorado School of Mines, Golden Co. 80401, 2008 